
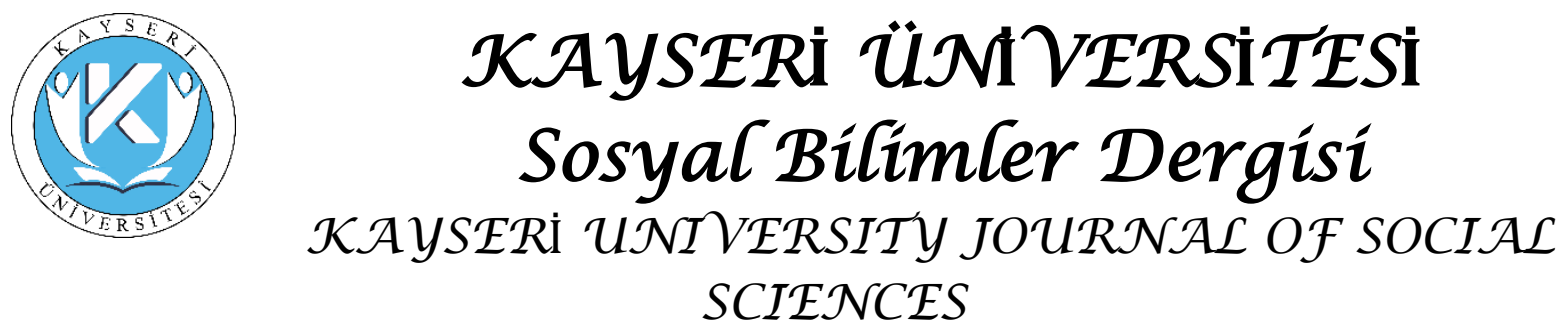

\begin{tabular}{|l|l|l|l|l|l|}
\hline Makale Türü & Araştırma Makalesi & Y1l & $\mathbf{2 0 2 1}$ & ss. & $\mathbf{2 9 - 4 5}$ \\
\hline Gönderi Tarihi & $\mathbf{1 0 . 1 0 . 2 0 2 1}$ & Cilt & $\mathbf{3}$ & DOI & $\mathbf{1 0 . 5 1 1 7 7 / k a y u s o s d e r . 1 0 0 7 7 5 3}$ \\
\hline Kabul Tarihi & $\mathbf{1 7 . 1 2 . 2 0 2 1}$ & Say1 & $\mathbf{2}$ & & \\
\hline Online Yayın Tarihi & $\mathbf{3 1 . 1 2 . 2 0 2 1}$ & Ay & Aralık & & \\
\hline
\end{tabular}

\title{
Kamu üniversitelerinde iş sağlığı ve güvenliği uygulama rehberi içerik analizi ${ }^{*} \Delta$
}

\section{Content analysis of the occupational health and safety practice guide in public universities}

\author{
(1) Ramazan KAYABAŞI \\ (1) Hatice ÖZDEMİR ${ }^{2}$ \\ İbrahim CÜNDÜBEYOĞLU ${ }^{3}$
}

$\ddot{O} \mathbf{z}$

Üniversiteler eğitim ve araştırma faaliyetlerini yürüten kurumlar olmanın yanı sıra aynı zamanda işyerleridir. Dolayısıyla İş Sağlığı ve Güvenliği (ISG) mevzuatı açısından yükümlülükleri bulunmaktadır. Üniversitelerde 6331 sayılı İSG Kanunun uygulanmasında farklılıklar oluşmakta ve uygulamada zorluklar yaşanmaktadır. Kamu Üniversitelerinde İSG Uygulama Rehberi, çalışanların farklı statüye sahip olması, teşkilat yapısının farklı olması ve birimlerinin farklı yerleşkelerde bulunması sebebiyle üniversitelere yol göstermek amacıyla yayınlanmıştır. Kamu kurumları ve özel işletmeler için yayınlanan uygulama rehberlerinin mevzuatla uyumlu olması beklenmektedir. Bu çalışmada Kamu Üniversitelerinde İSG Uygulama Rehberi yasal mevzuatla ilişkisi içerik analizi yöntemi ile incelenmiştir. Analiz için 2 ana kod ve 6 alt koddan oluşan bir kodlama sistemi kullanılmıştır. "Yasal mevzuata göre fazla içerik bulunan ifade" en fazla kodlamanın ( $\mathrm{f}=40$ ) yapıldığı ifadedir. Yasal mevzuata göre güncel olmayan hiçbir ifadeye rastlanmazken 18 ifade "yasal boşluk içeren ifade" olarak kodlanmıştır. Yasal boşluk içeren ifadelerin; İSG kurulları ile yönetimin İSG taahhütü başlıkları altında kümelendiği görülmüştür. Çalışmada rehberin üniversitelere sağlayacağı katkılar değerlendirilmiş̧; rehberin dışında kalan veya rehberde tam olarak cevabı bulunmayan maddeler tartışmaya açılmıştır.

Anahtar Kelimeler: Sağlık, Güvenlik, Mevzuat, Üniversitelerde İş Sağlığı ve Güvenliği

\section{Abstract}

Universities are not only institutions that carry out education and research activities, but also workplaces. Therefore, they have obligations in terms of Occupational Health and Safety (OHS) legislation. There are differences in the implementation of the OHS Law No. 6331 in universities and there are difficulties in implementation. The OHS Practice Guide in Public Universities has been published to guide universities due to the different status of their employees, the different organizational structure, and the fact that their units are located in different campuses. It is expected that the implementation guides published for public institutions and private enterprises will be in compliance with the legislation. In this study, the relationship between the OHS Practice Guide in Public Universities and the legal legislation was examined by content analysis method. A coding system consisting of 2 main codes and 6 subcodes was used for analysis. "Expression with too much content according to

\footnotetext{
${ }^{\Delta}$ Yazar bu çalışmanın tüm süreçlerinin araştırma ve yayın etiğine uygun olduğunu, etik kurallara ve bilimsel atıf gösterme ilkelerine uyduğunu beyan etmiştir. Aksi bir durumda Kayseri Üniversitesi KAYÜSOSDER Dergisi sorumlu değildir.

*Etik kurul izni gerektirmeyen çalışmalardandır.

${ }^{1}$ Öğr. Gör., Kayseri Üniversitesi, Tomarza Mustafa Akıncıŏ̆lu MYO, rkayabasi@kayseri.edu.tr

${ }^{2}$ Öğr. Gör., Kayseri Üniversitesi, Mustafa Çıkrıkçığlu MYO, haticeozdemir@kayseri.edu.tr

${ }^{3}$ İSG Uzmanı, Kayseri Üniversitesi, icundubeyoglu@kayseri.edu.tr
} 
Kayabaşı, R., Özdemir, $\mathcal{H}$. \& Cündübeyoğlu, i., (2021). Kamu üniversitelerinde iş săğğ $i$ ve güvenlĭğ uygulama rehberi içerik analizí.

the legal regulations" is the expression with the most coding $(\mathrm{f}=40)$. While no outdated expressions were found according to the legal legislation, 18 expressions were coded as "expressions containing legal gaps". Statements containing legal spaces; It has been observed that the OHS boards and the management are clustered under the headings of OHS commitment. In the study, the contributions of the guide to the universities were evaluated; Items that are out of the guideline or that do not have a complete answer in the guideline were opened for discussion.

Keywords: Health, Safety, Legislation, Occupational Health and Safety in Universities

\section{Giriș}

İş Sağllğı ve Güvenliği (İSG) farklı birçok disiplinden bilgi edinilmesini gerektiren multidisipliner bir alandır. Bu nedenle İSG çalışma hayatı ile ilgili bütün bilim dallarını ilgilendirmektedir. İSG akademik olarak multidisipliner bir alan olduğu kadar, uygulama sahasında; sağlık sektöründen imalat sektörüne, eğitim sektöründen hizmet sektörüne kadar çalışanın var olduğu tüm işletmelerde ve iş kollarında yer almaktadır. İSG çalışanların sağlık ve güvenliği, işletmelerin verimliliği ve sürekliliği için üzerinde çalışılması gereken güncel bir konudur. İşyerleri fiziki şartlarında yapılan değişiklikler, çalışanların değişimi, teknolojik gelişmeler, üretim yönteminde yapılan değişiklikler ve kullanılan hammaddenin değişimi gibi nedenler ile sürekli gözlemlenmesi gereken yerler olarak karşımıza çıkmaktadır. Bu değişimler çalışan eğitimlerinin güncel tutulması, çalışanlara sağlı gözetimi yapılması, iş ekipmanlarının periyodik kontrollerinin yapılması, makinelerin periyodik bakım ve onarımı gibi süreklilik isteyen konuları ortaya çıkarmaktadır. İşyerlerinde çok sayıda tehlike kaynakları ve riskler bulunmaktadır. Riskler düzeltici ve önleyici faaliyetlerin uygulanmaması halinde kazalara, yaralanmalara ve ölümlere neden olabilmektedir.

Türkiye'de 2013 ile 2020 yılları arasında görülen iş kazası, iş kazaları sonucu ölüm ve geçici iş göremezlik verileri Şekil 1'de verilmiş̧ir. 2013 yılı iş kazası geçiren çalışan sayısı 191.389 iken, sürekli artış göstererek 2019 yılında 422.463 olmuştur. Toplam çalışan sayısının artması bu durumu etkilemektedir. İş kazaları sonucunda 2013 yılında 1.360, 2019 yılında 1.149 çalışan hayatını kaybetmiştir. 2013 yılında geçici iş göremezlik gün sayısı 2.357.505 iken, 2019 yılında 3.627.934 olmuştur (SGK İş Kazası, Meslek Hastalığ1 ve iş Göremezlik İstatistikleri, 2013-2020). Geçici iş göremezlik verileri yıllara bağlı artış eğilimindedir. 2020 yılında iş kazası geçiren sigortalı sayısı bir önceki yıla göre azalmış olmasına rağmen, ölümlü iş kazası sayısında artış gözlemlenmektedir.

\section{Şekil 1}

Türkiye'de 2013-2020 Yılları Arasında İş kazası, İş Kazası Sonucu Ölüm ve İ̧̧ Göremezlik Verileri

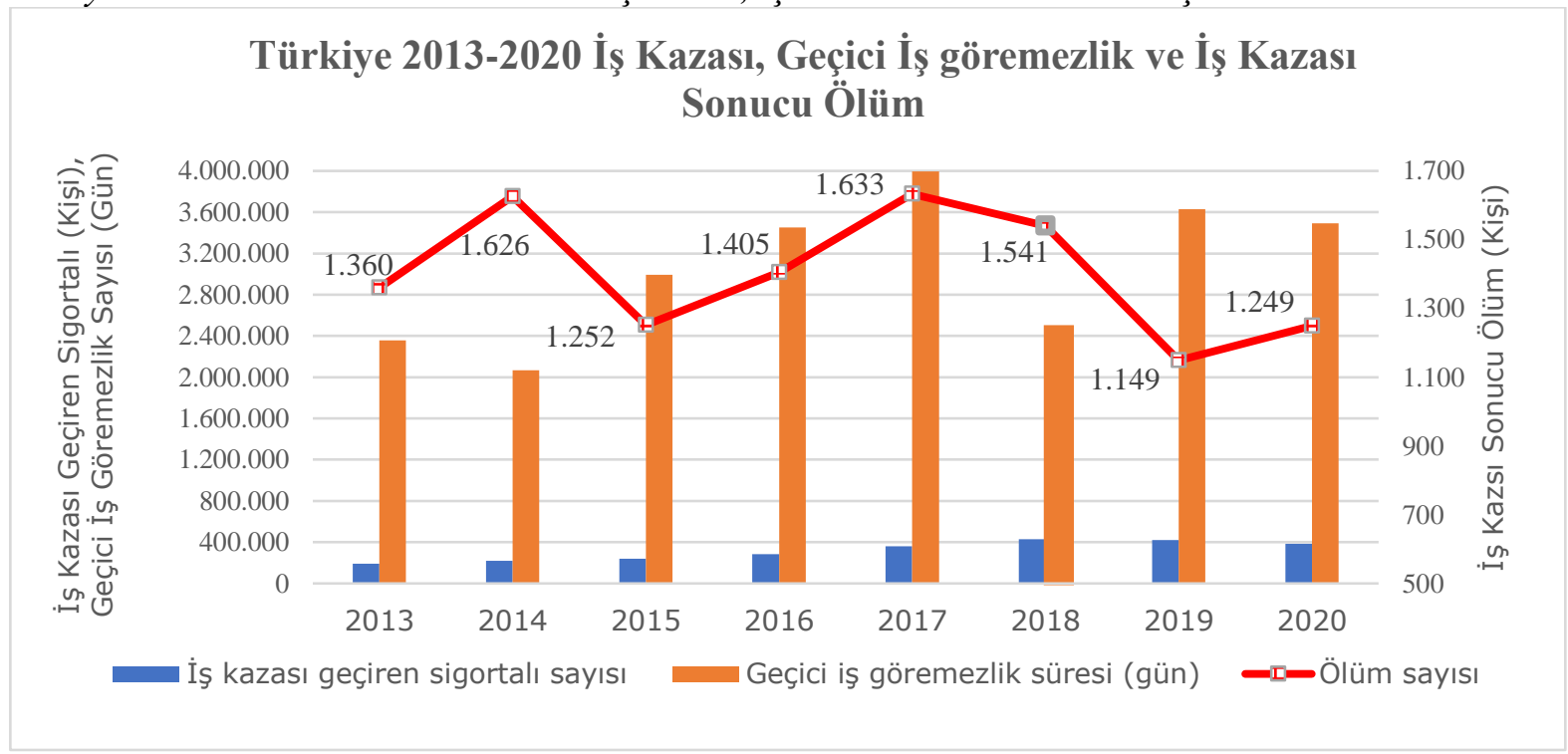

Kaynak: SGK (2021). İş Kazası, Meslek Hastalığı ve İş Göremezlik İstatistikleri, http://www.sgk.gov.tr 
Üniversiteler 2547 sayılı Yükseköğretim Kanunu kapsamında faaliyetlerini sürdüren, bilimsel özerkliğe sahip üst düzey eğitim veren kamu tüzel kişiliğine sahip kurumlardır. Eğitim, araştırma ve geliştirme faaliyetleri yürüten ARGE merkezleridir. Üniversiteler ayrıca bünyesinde akademik, idari ve diğer çalışılanlarıyla birlikte faaliyetlerine devam eden işyerleridir. Bünyesinde bulunan tüm birimler (fakülteler, yüksekokullar, meslek yüksekokulları, merkezler ve idari) çalışanlarıyla faaliyetlerini yürütmektedir. Üniversiteleri diğer işyerlerinden ayıran farklı yerleşkelere, farklı teşkilat yapısına sahip olması ve dolayısıyla faaliyetlerine yönelik tehlike sınıflarının değişmesidir. Öğrenci sayıları ve sosyal olarak halka açık kampüs alanları, bünyesinde bulunan birimlerin farklılı̆g 1 ve fiziki değişiklikler kampüsler arası farklılıklar olarak karşımıza çıkmaktadır. Üniversitelerde yürütülen faaliyetler ve çalışan sayıları değerlendirildiğinde İSG açısından üzerinde ayrıca durulması gereken büyük ve önemli kurumlardir.

Üniversitelerin teşkilat yapısı, faaliyetleri ve farklı yerleşkelere sahip olmaları, 6331 sayılı Kanunun uygulanmasında farklılıkları ortaya çıkmıştır. Uygulama birliğinin sağlanması için "Kamu Üniversitelerinde İSG Uygulama Rehberi” Çalışma ve Sosyal Güvenlik Bakanlığı'na bağlı İSG Genel Müdürlüğü (İSGGM) tarafindan Nisan 2021'de yayınlanmıştır (Kamu Üniversitelerinde İSG Uygulama Rehberi, 2021).

\section{Kamu üniversitelerinin İSG yükümlülükleri}

6331 sayılı sayılı İSG Kanunu işverenin genel yükümlülüklerini tanımlamaktadır. Kanunun 4. Maddesi, çalışanların işle ilgili sağlık ve güvenliğini sağlamakla ilgili yükümlüğü işverene vermektedir. Kanunun ilgili maddesi kapsamında işverenin sorumlulukları "Mesleki risklerin önlenmesi için gerekli tüm tedbirlerin alınması, organizasyonun yapılması, araç ve gereçlerin sağlanması, sağlık ve güvenlik tedbirlerinin değişen şartlara uygun hale getirilmesi ve mevcut durumun iyileştirilmesi için çalışmalar yapmak; ISS tedbirlerine uyulup uyulmadığını izlemek, denetlemek ve uygunsuzlukların giderilmesini sağlamak; risk analizi yapmak veya yaptırmak; çalışana görev verirken, çalışanın sağlık ve güvenlik yönünden işe uygunluğunu göz önüne almak; yeterli bilgi ve talimat verilenler dışındaki çalışanların, hayati ve özel tehlike bulunan yerlere girmemesi için gerekli tedbirleri almak" hükümleri ile tarif edilmektedir (Resmi Gazete, 2012, ss. 1-15). İşverenin sorumlulukları işyerinin tehlike sınıfına göre farklılık gösterebilmektedir. İSG'ne İlişkin Tehlike Sınıfları Tebliğine göre işyeri tehlike sınıfları faaliyet alanı NACE kodlarına göre ayrılmışıı. Böylelikle tebliğ işyerlerine karşıllık gelen (az tehlikeli, tehlikeli ve çok tehlikeli) tehlike sınıflarını belirlemiştir (İSG'ne İlişkin Tehlike Sınıfları Tebliği, 2012). Bu kapsamda kamu üniversiteleri "az tehlikeli” işyerleri kapsamında yer almaktadır (Tablo 1).

\section{Tablo 1}

\section{Tehlike Sinifi ve NACE Kodu}

NACE Rev. 2 Altill Kod

NACE Rev. 2 Altulı Tanım

Tehlike Sintfi

8542 Yükseköğretim

85.42 .01

Kamu kurumları tarafindan verilen yükseköğretim faaliyetleri

Az Tehlikeli (yükseköğretim düzeyinde eğitim veren konservatuarlar dahil)

Kaynak: Resmî Gazete (2012). İş Sağlığı ve Güvenliğine İlişkin Tehlike Sınıfları Tebliğ. (28509).

Az tehlikeli, tehlikeli, çok tehlikeli sınıflandırma ISG hizmetlerinin sunumu, İSG profesyonellerinin çalışma süreleri, çalışanlara verilecek eğitim saatleri veya çalışanların sağlik gözetimi yenileme süreleri gibi bazı uygulama farklılıklarını beraberinde getirmektedir. Bununla birlikte üniversitelerin farklı birimlere, merkezlere sahip olmaları farklı tehlike sınıflarının tanımlanmasını da zorunlu kılar. Üniversitenin bünyesindeki sağlık uygulama ve araştırma merkezleri "çok tehlikeli”, diş hekimliği uygulama ve araştırma merkezleri “tehlikeli” ve eğitim fakülteleri "az tehlikeli" sınıfta 
Kayabaşı, R., Özdemir, $\mathcal{H}$. \& Cündübeyoğlu, i., (2021). Kamu üniversitelerinde iş săg l̆ğ $i$ ve güvenlĭğ uygulama rehberi içerik analizí.

tanımlanması örnek olarak verilebilir. Ayrı ayrı işyeri SGK sicil numarasına sahip birimler sisteme dâhil edilmelidir.

Üniversite faaliyetlerinin az tehlikeli sınıfta yer almasından işyeri ortamında hiç tehlike bulunmadığı anlamı çıkarılmamalıdır. Ülkemizde meydana gelen iş kazaları ve meslek hastalıklarına ait resmi rakamlar, Sosyal Güvenlik Kurumu (SGK) tarafından yıllık "İ̧ Kazası ve Meslek Hastalığı İstatistikleri” tabloları ile yayınlanmaktadır. Kullanılan SGK verileri 2013-2020 yılları arasını kapsamaktadır ve 4a güvencesine sahip çalışanları içermekte olup ekonomik faaliyet sınıflamasında eğitim maddesinin altında yer alan "yükseköğretim” faaliyeti için verilen iş kazası ve meslek hastalıkları sayıları ve ölüm rakamları Tablo 2'de verilmiştir. Yükseköğretim kurumlarında 2015 ve 2019 yıllarında iş kazası sonucu ölüm sayısı 2 kişi iken 2016 yılında 1 kişi olarak görülmektedir. 2013-2020 yılları arasında yükseköğretim kurumlarında toplam 3 çalışana meslek hastalığı tanısı konulmuştur. 2019 yılında 1 meslek hastalığ 1 vakası varken 2020 yılında ise 2 çalışana meslek hastalığı tanısı konulmuştur. 2017 yılında 1 çalışan meslek hastalığı nedeniyle hayatını kaybetmiştir.

İş kazası sayısı ise 2013 ile 2019 yıllar arasında sürekli artmış olup 2020 y1lında 814 olarak kayda geçmiştir.

\section{Tablo 2}

Yükseköğretim Kurumları 2013-2019 Arasında İs Kazaları ve Meslek Hastalıkları

\begin{tabular}{ccccc}
\hline Yıllar & $\begin{array}{c}\text { İş Kazası } \\
\text { Sonucu Ölüm }\end{array}$ & $\begin{array}{c}\text { Meslek } \\
\text { Hastalığı }\end{array}$ & $\begin{array}{c}\text { İş Kazası } \\
\text { Sayısı }\end{array}$ & $\begin{array}{c}\text { Meslek } \\
\text { Hastalı̆̆ } \\
\text { Sonucu Ölüm }\end{array}$ \\
\hline 2020 & 0 & 2 & 814 & 0 \\
2019 & 2 & 1 & 1.381 & 0 \\
2018 & 0 & 0 & 956 & 0 \\
2017 & 0 & 0 & 621 & 1 \\
2016 & 1 & 0 & 272 & 0 \\
2015 & 2 & 0 & 145 & 0 \\
2014 & 0 & 0 & 128 & 0 \\
2013 & 0 & 0 & 71 & 0 \\
\hline Toplam & 5 & 3 & 4.388 & 1 \\
\hline
\end{tabular}

Kaynak: SGK, 2021

6331 sayılı Kanun ile kamu sektöründe çalışanlar da kanun kapsamına alınmıştır. Kamu işverenlerine de iş kazaları ve meslek hastalıklarını bildirim yükümlülüğünün gelmesi, kanunda öngörülen ağır idari para cezaları, kamu kurumlarında şekillenmeye başlayan İSG yapılanması ile kaza bildirimleri artmış bu durum iş kazası sayılarına yansımıştır. Ülkemizde resmi istatistiklere yansıyan meslek hastalıklarının sayısı beklenen rakamların altındadır (Berk, Önal, \& Güven, 2011, s. 2). Dünyada meslek hastalıkları oranları (her bin işçide 4-12), yıllık meslek hastalıkları sayısı 50-140 bin arasındadır. Fakat ülkemizde az sayıda meslek hastalığı vakası bildirilmektedir (Bilir, 2016, s. 62). Yayınlandığı günden itibaren proaktif yapısıyla öne çıkan İSG Kanunu incelendiğinde geniş ölçüde işverenin İSG yükümlülükleri üzerine yapılandırılmış olduğu görülür. Kanun tüm işverenlere olduğu gibi üniversite yönetimlerine de aşağıdaki sorumlulukları yüklemektedir.

\section{1. Çalışanlara ISG hizmetlerini sunma}

İşveren iş kazalarının ve ilerde ortaya çıkabilecek meslek hastalıklarının önlenmesi için işyerinde İSG hizmetlerinin sunumuna ilişkin bir yapılanmaya gitmek zorundadır. İşveren 6331 sayılı 
Kanun'un 6. Maddesine göre şu yollarla İSG hizmetini çalışanlarına sunabilir: İşveren çalışanları arasından iş güvenliği uzmanı, işyeri hekimi bulunması halinde görevlendirebilir. On ve daha fazla çalışanı olan çok tehlikeli sınıfta yer alan işyerlerinde diğer sağlık personeli görevlendirebilir. Personellerinden yeterliliği olan bulunmuyorsa ortak sağlık ve güvenlik birimlerinden hizmet alır. İşveren belirlenen niteliklere ve belgelere sahip ise, tehlike sınıfını ve çalışan sayısını dikkate alarak bu hizmeti yerine getirebilir. Ayrıca işveren Çalışma ve Sosyal Güvenlik Bakanlığınca ilan edilen eğitimleri alarak mevzuat çerçevesinde işyerinde hizmetleri üstlenebilir. Örneğin İSG Hizmetleri Yönetmeliği 5. Maddesi uyarınca işyerinde 50'den az çalışanı var ve işyeri az tehlikeli sınıfta yer alıyorsa işe giriş ve periyodik muayeneler ve tetkikler hariç İSG hizmetlerini kendisi yürütebilir (6331 İSG Kanunu).

\subsection{ISG profesyonelleri görevlendirme}

İşveren, işyeri tehlike sınıfına ve çalışan sayısına göre yeterli sayıda iş güvenliği uzmanı ve işyeri hekimi, diğer sağlık personeli görevlendirir. İSG Kanunu'nun 8. Maddesine göre işverene danışmanlık yapmak üzere görevlendirilen iş güvenliği uzmanları ve işyeri hekimleri tarafından yazılı olarak bildirilen önlem ve tavsiyelerin işveren tarafindan yerine getirilmesi gerekmektedir.

\subsection{Risk değerlendirmesi}

6331 sayılı Kanun'un 10. Maddesine göre işveren, işyerindeki tehlikeleri belirleyerek, riskleri tespit etmek, önem ve öncelik sırasına göre gereken tedbirleri almak ve çalışmaları başlatmakla yükümlüdür. İSG Risk Değerlendirmesi, işyerinde var olan ya da dişarıdan gelebilecek tehlikeleri belirlemek amacıyla yapılmaktadır. İşyeri risk değerlendirme ekibi bu tehlikelerin riske dönüşmesine neden olacak faktörleri belirleyerek riskleri analiz edecekler ve derecelendireceklerdir. Sonuç olarak kontrol tedbirleri belirlenerek ve sorumlular tayin edilerek gerçekleştirme süreleri kayda alınacaktır. Risk değerlendirmesi yapılırken risklerden etkilenecek personelin durumu dikkate alınmalıdır. İşyerinde kullanılacak iş ekipmanı ile kimyasal madde ve müstahzarların seçimi çalışanların sağlığı ve güvenliği düşünülerek yapılmalıdır. İşyerinin tertip ve düzeni, sağlık ve güvenliğe tehdit oluşturmayacak şekilde yapılmalıdır. İşyerinde (engelli, yaşlı, gebe, emziren veya genç çalışanlar) özel politika gerektiren gruplar ile kadın çalışanların durumu dikkate alınarak gerekli önlemler alınmalıdır. İşveren yapılan risk değerlendirmesi sonuçlarını dikkate alarak işyerinde gerekli bulunan ortam ölçümlerinin (gürültü, titreşim, aydınlatma, elektromanyetik alan, toz, gaz, termal konfor şartları vb.) yapılmasını sağlamakla yükümlüdür. İşveren risk değerlendirmesinde belirtilen riskleri kabul edilebilir seviyede tutmak için düzeltici ve önleyici çalışmalar yapmalıdır.

\subsection{Acil durumlar}

6331 sayılı Kanun'un 11. Maddesine göre işveren, işyerinde meydana gelebilecek acil durumları önceden değerlendirmelidir. İşveren etkilenmesi mümkün olan çalışanları korumak için muhtemel acil durumlara karşı önlemler almalıdır. Acil durumların olumsuz etkilerini önleyici ve sınırlandırıcı tedbirler alarak gidermelidir. Ayrıca acil durum planları hazırlanmalı ve acil kaçış planları çalışanların görebileceği uygun bir alana asılmalıdır. Ayrıca acil durum ekiplerine önleme, koruma, tahliye, yangınla mücadele, ilk yardım vb. konularda yeterli sayıda kişiyi görevlendirmelidir. Verilecek eğitim ve yapılacak tatbikatlarla ekiplerin her zaman hazır olması da sağlanmalıdır. İşveren ciddi, yakın ve önlenemeyen bir durumun meydana gelmesi halinde işi durdurmalıdır. Çalışanlar işi bırakarak derhal çalışma yerlerinden ayrılarak güvenli toplanma bölgesine yönelmelidir.

\section{5. İ̧ kazası ve meslek hastalığını kaydetme ve bildirme}

İşveren işyeri kapsamında değerlendirilen tüm işyeri ve eklentilerinde iş kazası ve meslek hastalığı görülmesi halinde kaydını tutmak zorundadır, İş kazaları SGK'ya kazadan sonraki üç iş günü içerisinde, meslek hastalıklarını ise kendisine bildirildikten sonra üç iş günü içerisinde SGK'ya bildirmek zorundadır. İşyerinde, yaralanma veya ölüme neden olmayan olaylar olması halinde; bu olayların çalışana veya işyerine zarar verme potansiyeli varsa kayıt altına alınmalıdır. Çalışanı veya iş 
Kayabaşı, R., Özdemir, $\mathcal{H}$. \& Cündübeyoğlu, i., (2021). Kamu üniversitelerinde iş sağ l̆ğ $i$ ve güvenlĭg i uygulama rehberi içerik analizí.

ekipmanı zarara uğratma potansiyeli olan olayları İSG kurulunda inceleyerek tekrarının yaşanmaması için önlemler almalıdır. İşveren kaza ve ramak kala olaylar ile ilgili raporları düzenlemek zorundadır. Proaktif yaklaşımın sürdürülebilir olması için ramak kala kayıtlarının tutulması ve ramak kala olaylarının incelenerek kök neden analizinin yapılması kazalara yönelik alınacak önemli bir önleme politikasıdır.

\subsection{Sağlık gözetimi}

İşveren çalıştıracağı kişileri işe girişlerinde, iş değişikliği olduğunda sağlık gözetimine tabii tutmalıdır. İşyerinde çalışan meslek hastalığı geçirmesi halinde ve iş kazası ardından işe dönüşlerde çalışana yapılan sağlık gözetimi tekrarlanmalıdır. Ayrıca işin devamı süresince mevzuatta belirtilen aralıklarla sağlık muayenesi yenilenmelidir. Sağlık muayenelerinde işin niteliği ile işyerinin tehlike sınıfı dikkate alınarak düzenli aralıklarla yenilenmesi işverenin sorumluluğundadır (Madde 15).

\section{7. Çalışanların İSG ĕgitimi ve bilgilendirilmesi}

6331 sayılı Kanun'un 16. Maddesine göre işveren, işyerinde karşılaşılabilecek sağlık ve güvenlik riskleri, koruyucu ve önleyici tedbirler, kendileri ile ilgili yasal hak ve sorumluluklar, ilk yardım, olağan dışı durumlar, afetler ve yangınla mücadele ve tahliye işleri konusunda görevlendirilen kişiler hakkında çalışanlarını bilgilendirmelidir. Aynı kanunun 17. Maddesine göre işveren çalışanlarına işe başlamadan önce, çalışma yeri veya iş değişikliğinde, iş ekipmanının değişmesi hâlinde veya yeni teknoloji uygulanması hâlinde İSG eğitimleri almasını sağlamalıdır. Ayrıca işe yeni başlayan çalışanlara işe başlama eğitimi verilmelidir. Eğitimler periyodik aralıklarla ve/veya çalışma şartlarında meydana gelen değişikliklere bağlı olarak tekrarlanır.

\section{8. Çalışan temsilcisi seçme}

6331 sayılı Kanun'da "İSG ile ilgili çalışmalara katılma, çalışmaları izleme, tedbir alınmasını isteme, tekliflerde bulunma ve benzeri konularda çalışanları temsil etmeye yetkili çalışan" çalışan temsilcisi olarak tanımlanmıştır (6331 sayılı Kanun). Her işyerinde tehlike sınıfı dikkate alınmaksızın çalışan sayısı gözetilerek yapılacak seçim veya seçimle belirlenemediği durumda atama yoluyla işveren tarafından çalışan temsilcisi görevlendirilir. Çalışan temsilcisi İSG kurulunun bir üyesidir ve çalışanları kurulda temsil etme ve çalışanların sözcülüğünü yapma hakkına sahiptir.

\section{9. $\quad$ Işs să̆ll̆̆g ve güvenliği kurulu}

İşveren, elli ve daha fazla çalışanın bulunduğu ve altı aydan fazla süren sürekli işlerin yapıldığı işyerlerinde İSG ile ilgili çalışmalarda bulunmak üzere kurul oluşturur (Madde 22). İşveren İSG mevzuatına uygun olarak alınmış kurul kararlarını da uygulamakla yükümlüdür.

\subsection{0. Çalışanların görüşlerini alma ve katılımlarını sağlama}

6331 sayılı Kanun'un 18. Maddesine göre çalışanların veya çalışan temsilcilerinin; İSG ile ilgili konularda görüşleri alınmalıdır, İSG konusunda teklif getirme hakkı verilmelidir. Ayrıca işyeri ile ilgili konularda görüşleri dikkate alınmalı ve İSG kurullarına katılımı sağlanmalıdır. İşveren alınması gereken koruyucu ve önleyici tedbirlerin belirlenmesinde çalışanların görüşüne başvurmalıdır. Koruyucu donanım ve ekipmanların belirlenmesi, sağlık ve güvenlik işaretlerinin belirlenmesinde çalışanların görüşü ve yapılan iş dikkate alınmalıdır. Bu durum tüm çalışanlarda İSG farkındalığının oluşmasına neden olacaktır. Böylelikle risklerinin önlenmesi ve koruyucu hizmetlerin yürütülmesi tüm paydaşların katılımı ile sağlanacaktır. Çalışanlara verilecek eğitimlerde bu hususlara değinilmeli ve alınan önlemler ile ilgili çalışanlar bilgilendirilmelidir.

Üniversiteler işyeri olarak kanunda yer alan hükümleri ve ikincil mevzuatla düzenlenmiş olan tüm sorumlulukları yerine getirmek zorundadır. Üniversiteler sorumluluklarını yerine getirirken, kanunun kamu kurumlarında uygulamaları şekillendirecek olan iş güvenliği uzmanı ve işyeri hekimi çalıştırma yükümlülüğünün ertelenmiş olması, uygulama farklılıklarını ortaya çıkarmış bu konudaki 
Kayseri Üniversitesi Sosyal Bilimler Dergisi. Cilt 3, Sayi: 2, Aralik 2021, 29-45

Kayseri University Journal of Social Sciences. Vol 3, NNo: 2, December 2021, 29-45

soruları çoğaltmıştır. Üniversitelerin İSG güvenliği yapılanmaları 10.07.2021 tarihinde resmi internet sayfalarında yer alan bilgilere göre analiz edilmiş sonuçlardır (Tablo 3). Tabloda kamu üniversiteleri, vakıf üniversiteleri ve vakıf meslek yüksekokulları da yer almaktadır.

Tablo 3

Üniversitelerin ISG Yapılanmaları

\begin{tabular}{ccccccccc}
\hline & Merkez & OSGB & Komisyon & Birim & Müdürlük & Koordinatörlük & $\begin{array}{c}\text { İnternet } \\
\text { Sitesinde } \\
\text { Belirtmeyen }\end{array}$ & Toplam \\
\hline $\mathrm{f}$ & 20 & 1 & 7 & 24 & 5 & 64 & 91 & 212 \\
$\%$ & 9,4 & 0,5 & 3,3 & 11,3 & 2,4 & 30,2 & 42,9 & 100 \\
\hline
\end{tabular}

Yükseköğretim Bilgi Yönetim Sistemi üzerinden ulaşılan verilerine göre mevcut üniversite sayımız 207 olup devlet üniversiteleri sayısı 129, vakıf üniversiteleri 74 ve vakıf meslek yüksekokulları sayısı 4'tür. 3 üniversitede hem merkez hem koordinatörlük, 2 üniversitede hem merkez hem birim dikkate alınmıştır $(\mathrm{f}=212)$. Üniversitelerin $\% 42,9$ 'unun internet sayfalarında İSG'ne ilişkin bir yapılanma hakkında bilgi yer almazken \%30,2 (f=64)'si İSG koordinatörlüğü, \%11,3 (f=24)'ü ise İSG birimi kurmayı tercih ettiği görülmektedir.

\subsection{Kamu üniversitelerinde ISG uygulama rehberi}

İSG konusu özellikle 6331 sayılı Kanun'un yayınlanmasının ardından pek çok araştırmacının dikkatini çekmiştir. İSG alanında lisansüstü düzeyde yapılan tezleri araştıran çeşitli çalışmalar mevcut olup (Mutlu \& Altuntaş, 2016, s. 2), (Özdemir \& Gündüz, 2018, ss. 2-3), (Ulutaşdemir vd., 2019, s. 3), (Ş. Keçeci, 2021, s. 2) göre; halk sağlı̆̆1, ergonomi, İSG saha gözlemleri ile yapılan durum tespiti çalışmaları, iş kazaları, risk analizi çalışmaları, İSG'nin hukuki boyutu, meslek hastalıkları, güvenlik kültürü, psikososyal riskler sıklıkla çalışılan konular arasındadır.

Üniversitelerin yapılanması ile ilgili yapılan bir çalışmada; dünyanın en iyi üniversitelerinde uygulanan İSG politika ve prosedürleri dikkate alınarak bir takip sistemi geliştirilmiştir. Bu sistem ülkemizdeki üniversitelerin teşkilat yapısına entegre olabilecek bir İSG çevrim içi yönetim takip sistemi haline getirilmiştir (G. Çivi, 2016, ss. 1-2). Üniversitelerin kendi kampüslerini (işyerlerini) esas alarak yürüttükleri çalışmalara bakıldığı zaman bir biriminin İSG açısından incelenmesini içeren saha çalışmaları, araştırma makaleleri arasında öne çıkmaktadır. Hitit Üniversitesi Teknik Bilimler Meslek Yüksekokulu İnşaat bölümü öğrenci ve akademisyenlerine anket uygulanmış öğrencilerin İSG bilgi düzeyleri, İSG uygulamaları, verilen eğitimler, istek ve şikâyetlerinin araştırılması ve çözüm önerilerinin belirlenmesi amaçlanmıştır (Cumhur \& Ahıskalı, 2018, ss. 2-3).

“İş Güvenliği Kültürü ve Üniversiteler” başlığı ile yayınlanan araştırma;

Kurumların güvenlik kültürü, kurumda görev yapan çalışanların İSG açısından olaylara vermiş olduğu tepki ve davranışları ortaya koymaktadır. Üniversite çalışanları ve öğrencileri benimsemiş oldukları İSG kültürü ile, üniversitelerin gelişmesine neden olacaklardır. Ayrıca mezun olan öğrenciler çalışacakları işyerlerinde davranışları ve bilgileriyle pozitif yönde İSG'ni etkileyecektir (C. Şensöğüt, 2018, s. 1), (Gül vd., 2018, s. 2). Üniversitelere yönelik yürütülen bir başka çalışmada akademisyenlerin çalışma performansını azaltacak iş kazaları ve meslek hastalıkları araştırılmış, risklere yönelik önleyici ve iyileştirici faaliyetler önerilmiştir. Sonuç olarak zamanla ortaya çıkması mümkün olan sağl1k sorunlarına ilişkin öneriler geliştirilmiştir (Şahin vd., 2019, ss. 15-16).

İSGGM tarafından "Kamu Üniversitelerinde İSG Uygulama Rehberi” yayınlanmıştır (Kamu Üniversitelerinde İSG Uygulama Rehberi, 2021). Rehber üniversitelerde İSG yapılanması, işveren vekili, İSG yönetim birimi, İSG kurulu ve İSG profesyonelleri ana başlıklarından oluşmakta olup uygulamada çok tartı̧̧lan konulara açıklık getirmeye çalışmıştır. Bu çalışma ile "Kamu Üniversitelerinde İSG Uygulama Rehberi’nin güncel mevzuat ışığında incelenmesi amaçlanmıştır. Bu 
Kayabaşı, R., Özdemir, $\mathcal{H}$. \& Cündübeyoğlu, i., (2021). Kamu üniversitelerinde iş sağ l̆ğ $i$ ve güvenlĭg i uygulama rehberi içerik analizí.

bağlamda araştırmanın kamu üniversitelerinde İSG yapılanma çalışmalarına katkı sunması ve belirlenecek olumlu ve olumsuz noktalarla birlikte daha sonra yapılacak araştırmalara yol göstermesi beklenmektedir.

\section{Yöntem}

\subsection{Araştırmanın amacı ve önemi}

6331 sayılı İSG Kanunu kamu ve özel tüm işyerlerinde uygulanmak üzere yayınlanmıştır. Dolayısıyla üniversiteler de bir işyeri olarak kanunun kapsamındadırlar. Kendi özel kanunlarındaki statülerine sahip çalışanlar, diğer işyerlerinden farklı yapılanmış olmaları, üniversiteye bağlı olmakla birlikte ayrı ayrı işyeri olarak tanımlı çok sayıda birim ve fiziksel olarak da birbirinden ayrı kampüs alanları kanunun uygulanmasında da pek çok soru, sorun ve uygulama farkını beraberinde getirmiştir. Yayınlanmış olan rehberin ana çıkış noktası mevzuat hükümlerinin uygulanması konusunda kamu üniversitelerine yol gösterirken uygulama birliği sağlanmasına da katkı sağlamaktır. Yapılan çalışmanın amacı yayınlanan rehberi yasal mevzuatla bağlamında incelemek ve elde edilen bulgular dikkate alarak diğer araştırmacılara ve üniversitelerde İSG'nin uygulama tarafında bulunan işveren vekilleri, iş güvenliği uzmanları ve işyeri hekimlerine yol göstermektir.

\subsection{Veri toplama ve yöntem}

$\mathrm{Bu}$ araştırma, nitel araştırma yöntemleri kullanılarak yapılan betimsel bir araştırmadır (G. Arastaman, 2018, s. 2). Veri toplama yöntemi olarak doküman analizinin adımları takip edilmiştir. Çalışmanın temelini oluşturan veri, Çalışma ve Sosyal Güvenlik Bakanlığı İSGGM'nün Nisan 2021 tarihinde yayınlamış olduğu "Kamu Üniversitelerinde İSG Uygulama Rehberi”dir (17 sayfa). Söz konusu rehbere İSGGM internet sitesinde "yayınlar" sayfasından 08.09.2021 tarihinde ulaşılmıştır. Rehberde geçen İSG mevzuatının güncel haline Mevzuat Bilgi Sistemi (www.mevzuat.gov.tr) kullanılarak ulaşılmıştır.

Rehberde yer alan her cümle numaralanmış ve belirlenen tema altında içerik analizi yöntemi ile kodlanmıştır. İçerik analizi, metinlerden (veya diğer anlamlı maddelerden) kullanım bağlamlarına ilişkin tekrarlanabilir ve geçerli çıkarımlar yapmak için bir araştırma tekniğidir (K. Krippendorff, 2018, ss. 3-5). Bir başka tanıma göre içerik analizi, doküman türündeki kanıtsal belgelere bilimsel yöntemlerin uygulanmasıdır (A. Hepkul, 2020, s. 2). İçerik analizleri, araştırma bilgilerini yaymada önemli rol oynayan ve daha ileri araştırmalar, politikalar, uygulamalar ile kamu algısını şekillendiren araştırma sentezleridir (Çalık \& Sözbilir, 2014, ss. 2-3).

$\mathrm{Bu}$ araştırmanın bazı sınırlılıkları bulunmaktadır. İSGGM tarafindan 6331 sayılı İSG Kanunu'nun farklı sektörlerdeki uygulamalarında yaşanan sorunlara kılavuzluk etmek amacıyla rehberler yayınlanmış, yayınlanmaya da devam etmektedir. Bu çalışma yayınlanmış olan rehberlerden "Kamu Üniversitelerinde İSG Uygulama Rehberi” ile sınırlandırılmıştır. Özel üniversiteler araştırma kapsamına dahil edilmemiştir. Kodlama yapılırken rehberin 5-12. sayfaları arasındaki başlıklar dikkate alınmış, rehberde yer alan önsöz, beş adımda üniversiteler ne yapmalı ve notlar başlıkları kodlama dışında tutulmuştur.

Kodlamalar rehberdeki cümleler esas alınarak yapılmıştır. Araştırma için belirlenmiş olan kategori "ISG mevzuatına göre inceleme" olarak isimlendirilmiştir. Verilerden çıkan kavramlara göre kodlama yapılmıştır (Z. Karataş, 2015, s. 2). Kodlamaların güvenilirliğini arttırmak amacıyla ayrıntılı literatür taraması yapılmış (Toprakçı \& Bulut, 2021, s. 16); (Baytekin \& Kaynar, 2021, s. 89); (Tonbul \& Çiğdem, 2020, s. 36) ana eksen rehberin mevzuatla kıyaslanması olduğu için verilerin kodlanmasında ana ve alt kodlar kullanılmıştır: 1 . ana kod (Rehberin İSG mevzuatı ile ilgili tutarlılığı) 1 alt koddan (Yasal mevzuata uygun) ve 2. ana kod (Rehberin İSG mevzuatı ile ilgili tutarsızlığı) 5 alt koddan (yasal mevzuata uygun, yasal mevzuata göre farklı ifade, Yasal mevzuata göre eksik ifade, yasal mevzuata göre fazla içerik olan ifade, yasal mevzuata göre güncel olmayan ifade) oluşmaktadır. 
Kayseri Üniversitesi Sosyal Bilimler Dergisí. Ciltt 3, Sayi: 2, Aralik 2021, 29-45

Kayseri University Journal of Social Sciences. Vol 3, NNo: 2, December 2021, 29-45

Tema, ana kodlar, alt kodlar ve alt kodlamalar yapılırken kullanılan ifadelerin ne anlama geldiği Tablo 4'te yer almaktadır:

\section{Tablo 4}

Kamu Üniversitelerinde İs Sağlığı ve Güvenliği Uygulama Rehberinin Yasal Mevzuat Temelinde Incelenmesine Ilisskin Kodlama Sistemi

\begin{tabular}{|c|c|c|c|}
\hline Tema & Ana Kodlar & Alt Kodlar & Alt Kod İçin Açıklama \\
\hline \multirow{6}{*}{$\begin{array}{c}\text { Kamu } \\
\text { Üniversitelerin- } \\
\text { de İş Sağlığı ve } \\
\text { Güvenliğ } \\
\text { Uygulama } \\
\text { Rehberinin İSG } \\
\text { mevzuatına göre } \\
\text { incelenmesi }\end{array}$} & $\begin{array}{l}\text { 1-Rehberin İSG } \\
\text { mevzuatı ile } \\
\text { tutarlılığ1 }\end{array}$ & $\begin{array}{l}1.1 \text { Yasal mevzuata } \\
\text { uygun }\end{array}$ & $\begin{array}{l}\text { Rehberde yer alan ifadenin mevzuat maddesi } \\
\text { vererek issaret etmesi veya ifadenin mevzuatla } \\
\text { örtüşsmesidir. }\end{array}$ \\
\hline & \multirow{5}{*}{$\begin{array}{l}\text { 2-Rehberin ISG } \\
\text { mevzuatı ile } \\
\text { tutarsızlığ } 1\end{array}$} & $\begin{array}{l}\text { 2.1 Yasal mevzuata } \\
\text { göre farklı ifade }\end{array}$ & $\begin{array}{l}\text { Rehberde yer alan ifadenin ilgili yasal } \\
\text { mevzuatla çelişmesidir. }\end{array}$ \\
\hline & & $\begin{array}{l}2.2 \text { Yasal mevzuata } \\
\text { göre eksik ifade }\end{array}$ & $\begin{array}{l}\text { Rehberde atıf yapılan yasal mevzuata eksik } \\
\text { değinilmesidir. }\end{array}$ \\
\hline & & $\begin{array}{l}2.3 \text { Yasal mevzuata } \\
\text { göre fazla içerik } \\
\text { bulunan ifade }\end{array}$ & $\begin{array}{l}\text { Rehberde yer alan ifadelerin mevzuatın } \\
\text { yorumlanarak ek olarak yazılan ifadeler, } \\
\text { verilen örneklerdir. }\end{array}$ \\
\hline & & $\begin{array}{l}2.4 \text { Yasal mevzuata } \\
\text { göre güncel olmayan } \\
\text { ifade }\end{array}$ & $\begin{array}{l}\text { Rehberde yer alan ifadenin konusu olan } \\
\text { mevzuatta değişiklik olması, iptal edilmiş } \\
\text { olması vb. durumlardır. }\end{array}$ \\
\hline & & $\begin{array}{l}2.5 \text { Yasal boşluk } \\
\text { içeren ifade }\end{array}$ & $\begin{array}{l}\text { Rehberde yer alan ifadenin yasal mevzuat } \\
\text { içerisinde hiç yer almamasıdır. }\end{array}$ \\
\hline
\end{tabular}

\subsection{Araştırmanin geçerlilik ve güvenirliğ $i$}

İçerik analizi tekniğinin güvenilirliği özellikle kodlama işlemine bağlıdır. Kategorilerin belirlenmesi ve açık seçik olarak tanımlanması en önemli aşamadır. Bu yapıldığı sürece analizin güvenilirliği ve nesnelliği artmış olacaktır. Güvenilirliğin test edilebilmesi için bazı tekniklerin kullanılması gerekir. İlk olarak, belgeler değişik araştırmacılara verilir ve her birinden elde edilen sonuçlar arasındaki korelasyon hesaplanır. Bu, araştırmacılar arasındaki güvenilirliktir. İkinci olarak, aynı araştırmacılara aynı belgeler iki farklı zamanda verilir ve aralarındaki korelasyon hesaplanır (Yüksel, 2015, s. 2).

Çalışmada öncelikle araştırmacılar tarafından yapılan toplantılarda kodlamaların cümle-cümle yapılmasına karar verilmiştir. Rehber defalarca okunduktan sonra kullanılacak ana kod ve alt kod listesine son hali verilmiştir. Çalışmada araştırmacıların ne kadar tutarlı kodlama yaptığını belirlemek üzere kodlama güvenilirliğine bakılmıştır. Bunun için iki ayrı araştırmacı tarafından birbirinden bağımsız olarak kod listesi kullanılarak kodlamalar yapılmış ardından bir araya gelinerek benzer olarak kodlanan ve uzlaş1lamayan maddeler görüşülmüştür. Kodlama güvenirliği, uyum yüzdesi (percent of agreement) indeksi kullanılarak hesaplanmıştır. Uyum yüzesi, aynı kodlamanın yapıldığı durumların, mevcut tüm durumlara (üzerinde uzlaşmaya varılan ve varılamayan kodlama durumları) oranı hesaplanarak bulunan bir indekstir. Bu şekilde uyum yüzdesi kullanılarak kodlama güvenirliği yüzdesi 83,5 bulunmuştur. Kullanılan uyum yüzdesinin 70 'ten daha yüksek olması beklenir (Tavşancıl \& Aslan, 2001, ss. 3-5). Sonuç olarak, kodlama güvenirliğinin kabul edilebilir düzeyde olduğu söylenebilir. Yapılan çalışmanın geçerlilik koşulunu yerine getirmek için araştırmanın her aşaması, amacından yola çıkılarak elde edilen sonuçlar detaylı olarak açıklanmıştır (Yüksel, 2015, s. 3). Yapılan toplantılar sonucunda elde edilen tüm veriler ve üzerinde çalışılan kodlama kayıtları saklanmıştır. 
Kayabaşı, R., Özdemir, $\mathcal{H}$. \& Cündübeyoğlu, i., (2021). Kamu üniversitelerinde iş săglı̆g $i$ ve güvenlĭğ uygulama rehberi içerik analizi.

\section{Bulgular}

Rehber incelenerek ana kodlar, alt kodlamalar oluşturulmuş ve dağılımlarını içeren Tablo-5 hazırlanmıştır. Rehberin cümle-cümle kodlanması tercih edilmiş olup rehberde toplam 66 cümle tespit edilmiştir. Kodlama yapılırken birden fazla alt kodla ilişkili ifadeler tespit edilmişse bu cümle birden fazla kodlama (Güngör, 2020, s. 2) yapılmıştır. Örneğin rehberde geçen "Yönetimin İSG konusunda ortaya koyduğu bu taahhüt sayesinde çalışanlarca İSG daha kolay benimsenecek, üniversitelerin tüm uygulamalarında ISG bir keyfiyet olmaktan uzak ana unsurlardan biri olarak ele alınacaktır" ifadesi hem "yasal mevzuata göre fazla içerik bulunan ifade" hem de "yasal boşluk içeren ifade" olarak kodlanmıştır.

Toplam yapılan kodlama sayısı 85 ’tir.

\section{Tablo 5}

Kamu Üniversitelerinde $\dot{I}_{S}$ Sağlı̆̆ ve Güvenliği Uygulama Rehberinin Yasal Mevzuat Temelinde Incelenmesine İlişkin Kodlama Sistemi

\begin{tabular}{|c|c|c|c|}
\hline Tema & Ana kodlar & Alt Kodlar & $\begin{array}{c}\text { Frekans } \\
(f)\end{array}$ \\
\hline $\begin{array}{l}\text { Kamu } \\
\text { Üniversitelerinde } \\
\text { İş Sağlığ ve } \\
\text { Güvenliği } \\
\text { Uygulama } \\
\text { Rehberinin İSG } \\
\text { mevzuatına göre } \\
\text { incelenmesi }\end{array}$ & $\begin{array}{l}\text { 1-Rehberin İSG } \\
\text { mevzuatı ile } \\
\text { tutarlılığ } 1\end{array}$ & $\begin{array}{l}\text { 1.1 Yasal mevzuata uygun } \\
\text { 2.1 Yasal mevzuata göre farklı ifade } \\
\text { 2.2 Yasal mevzuata göre eksik ifade } \\
\text { 2.3 Yasal mevzuata göre fazla içerik bulunan } \\
\text { ifade } \\
\text { 2.4 Yasal mevzuata göre güncel olmayan ifade } \\
\text { 2.5 Yasal boşluk içeren ifade } \\
\text { Toplam }\end{array}$ & $\begin{array}{c}14 \\
11 \\
2 \\
40 \\
0 \\
18 \\
85\end{array}$ \\
\hline
\end{tabular}

Ana Kod 1: Rehberin ISG Mevzuatı ile Tutarlılı̆̆

Alt Kod 1.1: Yasal Mevzuata Uygun

Rehberde yer alan ifadeler İSG mevzuatı ile karşılaştırıldığında 14 ifadenin işaret ettiği veya direkt olarak atıfta bulunduğu yasal ifade ile tutarlı olduğu ve örtüştüğü görülmüştür. Rehberde yer alan bu duruma göre yapılan kodlamalara aşă̆ıdaki ifadeler örnek olarak verilebilir:

“Üniversiteler; 2547 sayılı Yükseköğretim Kanunu'nda bulunan "Bilimsel özerkliğe ve kamu tüzel kişiliğine sahip yüksek düzeyde eğitim- ögretim, bilimsel araştırma, yayın ve danışmanlık yapan; fakülte, enstitü, yüksekokul ve benzeri kuruluş ve birimlerden oluşan bir yükseköğretim kurumudur." hükmü uyarınca kurulmuştur",

“2547 say1lı Yükseköğretim Kanunu’nda "Rektör, üniversite veya yüksek teknoloji enstitüsü tüzel kişiliğini temsil eder."

İSG Kanunu 22. maddesi gereğince 50'den fazla çalışanı olan ve altı aydan fazla sürekli işlerin yapıldığı işyerlerinde İSG Kurulunun (İSG Kurulu) kurulması gerekmekte olup bu kurulların oluşumları, görev, yetki ve sorumlulukları, kurul üyelerinin eğitimleri ve benzeri hususlar "ISG Kurulları Hakkında Yönetmelik'te yer almaktadır”.

Ana Kod 2: Rehberin ISSG Mevzuatı ile Tutarsızlı̆̆

Alt Kod 2.1: Yasal Mevzuata Göre Farklı Ifade 
Rehberin İSG mevzuatı ile tutarsızlığı; yasal mevzuata göre farklı ifade, yasal mevzuata göre eksik ifade, yasal mevzuata göre fazla içerik bulunan ifade, yasal mevzuata göre güncel olmayan ifade, yasal boşluk içeren ifade olmak üzere 5 ayrı alt koddan oluşmaktadır. Bu kodlar altında toplamda 71 ifade kodlanmıştır.

Yasal mevzuata göre farklı ifade $(\mathrm{f}=11)$, rehberde yer alan ifadenin yasal mevzuatta yer alan ifade ile farklılık göstermesi durumunda kullanılmıştır. Örneğin rehberde;

"ISG kurullarında alınan kararların irdelenmesi ve uygulamada aksaklık yaşanmaması için yılda 2 defadan az olmamak üzere de rektör ya da rektör yardımcısı başkanlığında İSG Koordinasyon Kurulunun toplanması koordinasyonun sağlanması açısından oldukça önemlidir" ifadesi yer almaktadır.

İSG Kurulları Hakkında Yönetmeliğe göre koordinasyonun sağlanması işverenin görevi olup birden çok işyerinin her birinde kurulacak kurulların en az 3 ayda bir, işyerine ait raporların ilgili teknik eleman ve uzmanlarca incelenmesininim sağlanması hükmü yer almaktadır (Madde 5).

Rehberde "Ayrıca ihtiyaca göre kurulan kurullarda akademik birimler özelinde yapılanmaya gidilebilir" ifadesi de bu bölümde kodlanmıştır. İSG Kurulları Hakkında Yönetmeliğe göre kurulun oluşumunda esas alınan temel kriter sürekli işlerin yapıldığı işyerlerinde elli ve daha fazla çalışanın bulunmasıdır. Yönetmelikte kurulun oluşumunda tehlike sınıfı veya birimlerin faaliyetleri dikkate alınmamaktadır. Tehlike sınıfi yalnızca toplantı periyotlarının belirlenmesinde temel oluşturur. Üniversitelerin farklı SGK sicil numarasına sahip birimleri ayrı bir "işyeri" kimliğine sahip iseler ilgili yönetmeliğe göre "elli ve daha fazla çalışanın bulunduğu her bir işyerinde ayrı ayrı kurul kurulması (Madde 5) gerekli iken yerleşke, akademik birimler, tehlike sınıfları özelinde daha farklı bir yapı ortaya çıkarmaktadır.

Rehberde geçen, "Bir başka deyişle üniversite bünyesinde birden fazla sicil numarası olsa dahi yapılacak ISSG profesyoneli görevlendirmelerinde de İSG kurulu oluşturulurken değerlendirmeye alınan yerleşke bazlı ya da faaliyet bazlı yaklaşım göz önünde bulundurulabilir" ifadesi bu alt kodla kodlanmıştır. Yerleşke bazlı ya da faaliyet bazlı yaklaşım ISG profesyonellerinin görevlendirilmesinde uygulanırken bir önceki maddede yer verildiği gibi birimlerin SGK sicil numaraları ile İSG-Katip sistemi üzerinden tüm bileşenleri içerisine alacak biçimde yerleşkelerde veya tehlike sınıflarına göre birimlerde görevlendirmeler yapılmalıdır.

Yasal mevzuata göre farklı kodlanan 11 maddeye bakıldığ 1 zaman 4 madde dışında İSG kurulları ile ilişkili olduğu görülmüştür. Birbirinden farklı tehlike sınıfları ve bütün yerleşkenin aynı alanda bulunmaması, çok sayıda SGK sicil numarasına sahip olma, çalışanların statülerinden kaynaklanan farklılıklar üniversitelerde kurul yapılanmalarını da birbirinden farklı olmasına yol açmaktadır. Rehberle yasal mevzuat arasındaki farklılıklar özellikle de yapılacak denetimlerde sorun teşkil edebilir. $\mathrm{Bu}$ açıdan İSG Kurulları Hakkında Yönetmeliğin özellikle kamunun ihtiyaçları çerçevesinde gözden geçirilmesi faydalı olacaktır.

\section{Alt Kod 2.2: Yasal Mevzuata Göre Eksik Ifade}

Yasal mevzuata göre eksik ifade $(\mathrm{f}=2)$ rehberde geçen ifadenin yasal mevzuat ile karşılaştırıldığında eksik ifade edilen cümlelerden oluşmaktadır.

Örneğin rehberde "Üniversitelerde ISG ile ilgili teknik çalışmaları planlamak, uygulamaları hayata geçirmek ve gerekli takipleri yapmak üzere bir birim kurulmalıdır" ifadesi bu kodda yer almaktadır. İşverenin bazı koşullara bağlı olarak işyeri sağlık ve güvenlik birimi kurma yükümlülüğü 6331 sayılı İSG Kanunu, İş Güvenliği Uzmanlarının Görev, Yetki, Sorumluluk ve Eğitimleri Hakkında Yönetmelik, İşyeri Hekimi ve Diğer Sağlik Personelinin Görev, Yetki, Sorumluluk ve Eğitimleri Hakkında Yönetmelik kapsamında açıklanmıştır. Ancak rehberde geçen birimin, yasal mevzuata doğrudan atıf verilmediği için işyeri sağlık ve güvenlik biriminden ziyade üniversitelere bırakılmış bir yapı tercihiyle kurulması önerilen bir birimdir. Üniversiteler bu durumda hali hazırda kurmuş oldukları koordinatörlük, müdürlük, İSG birimi, İSG komisyonu, ISG eğitim, uygulama ve araştırma merkezi gibi yapılarla bu hizmetleri çalışanlarına sunacaktır. 
Kayabaşı, R., Özdemir, $\mathcal{H}$. \& Cündübeyoğlu, i., (2021). Kamu üniversitelerinde iş săglı̆g $i$ ve güvenlĭğ uygulama rehberi içerik analizi.

Rehberde yer alan "Yapılan çalışmalar ve uygulama örneği değerlendirmeleri sonucunda üniversiteler özelinde; rektör veya rektör yardımcısı ISG işveren vekili olarak belirlenebilir" cümlesi de eksik ifade alt kodu ile kodlanmıştır. İşveren ve işveren vekili kavramları hukukta çok tartışılan kavramların başında gelmektedir. 6331 Sayılı Kanun'un 3. Maddesinde: "işveren-çalışan istihdam eden gerçek veya tüzel kişi yahut tüzel kişiliği olmayan kurum ve kuruluşları," şeklinde tanımlanmıştır. Aynı maddenin ikinci fikrasında da "işveren vekili-işveren adına hareket eden, işin ve işyerinin yönetiminde görev alan işveren vekilleri, bu kanun bakımından işveren sayılır." denilerek işin ve işyerinin yönetiminde görev alan işveren vekillerinin işveren sayılacağı hüküm altına alınmıştır. Bu durumda rehberde yer almasa da birimin yönetiminde görev alan, işveren adına hareket eden, emir ve talimat veren görev ve yetki sınırlarına göre yöneticiler; dekanlar, müdürler, genel sekreter, daire başkanları vb. işveren vekili olarak görev yapmaktadır. Rehbere bu cümlenin eklenmesi de tarafların ve sorumluluklarının farkına varmalarını sağlayacaktır.

\section{Alt Kod 2.3: Yasal Mevzuata Göre Fazla Içerik Bulunan Ifade}

Yasal mevzuata göre fazla içerik bulunan ifade ile mevzuata ek olarak yazılan bilgiler, açıklamalar, verilen örnekler kodlanmıştır. Bu bölüm en fazla kodlamaya sahip ( $\mathrm{f}=40)$ bölüm olup bir rehberin işlevinin açıklama yapmak, mevcut durumu somutlaştırarak ve örneklerle zenginleştirmek olduğu düşünülürse ek açıklamaların gerekli olduğu söylenebilir. Fazla içerik bulunan ifadelere şu kodlamalar örnek olarak verilebilir:

"Üniversitelerde farklı teşkilat yapılanmalarının olması sebebiyle 6331 sayı1ı İSG Kanunu uyarınca yapılacak uygulamalarda zorluklar yaşanmakta ve üniversiteler arasında farklılıklar ortaya çıkmaktadır".

"Mevzu bahis ifade gereğince üniversitelerin sahip olduğu tüzel kişilik işveren, bu işverenin işveren vekili ise rektördür".

“ISG tedbirlerinin işyerlerinde etkin şekilde uygulanması ve tüm çalışanlarca İSG kültürünün benimsenmesi için işverenlerin ISSG'ne verdikleri önemi ve desteği açıkça dile getirmeleri son derece önemlidir".

"Üniversite bünyesinde tek bir kurul kurulması durumunda rektörün ya da yetkili rektör yardımcısının işveren vekili olarak kurula başkanlık etmesi uygun olacaktır”.

"ISG hizmetlerinin sunumunda temel anlayışın tüm çalışanların kapsanması olduğu unutulmadan, etkinliği ve verimliliği artıracak şekilde, yasal hükümler dahilinde kalınarak görevlendirmelerin yapılması yerinde olacaktır”.

"Kampüs dışında farklı bir yerleşkede ise üniversitenin diğer bir ana hizmet birimi olan ve 57 kişinin çalıştığı ayrı bir işyeri sicil numarasına sahip yüksekokul olduğunu düşünelim”.

\section{Alt Kod 2.4: Yasal Mevzuata Göre Güncel Olmayan Ifade}

Yasal mevzuata göre güncel olmayan ifade ile kodlanan herhangi bir ifade kodlanmamıştır.

Alt Kod 2.5: Yasal Boşluk Iç̧eren Iffade

Yasal boşluk içeren ifade $(\mathrm{f}=18)$; rehberde geçen ifadenin yasal mevzuat içerisinde hiç yer almaması durumunda kodlanmıştır. Örneğin;

"Bu hususu sağlamak üzere, işyerinde İSG’ne verilen önemi anlatan bir İSG politikası oluşturulmalı ve yönetimce bu politikanın uygulanacağı taahhüt edilmelidir".

"Bu politika ve bu hususta işverence verilecek taahhüt; üniversitelerde yapılacak tüm çalışmalarda uygulanmak üzere belirlenmeli ve tüm çalışanlara duyurulmalıdır”.

"Yönetimin İSG taahhüdü belirli aralıklarla gözden geçirilmeli, uygulanabilirliği kontrol edilmeli ve değişen ihtiyaçlara göre güncellenmelidir".

Yukarıda yer alan ifadeler rehberde "Yönetimin İSG Taahhüdü" başlığı altında yer alan ifadeler olup ISO 45001 İSG Yönetim Sistemi Standardı kapsamında geçen şartlardır. Politika bir işyerinde üst 
yönetimin İSG konusundaki niyetini ortaya koyduğu metinlerdir. İşyerlerini daha güvenli ve sağlıklı bir yere dönüştürmek çalı̧̧anların proaktif yaklaşım benimsemesini sağlamak üzere, yönetim sisteminin kurulabilmesi için herkesle paylaşılan bir İSG politikasına ihtiyaç vardır.

Aşağıda yer alan örnek ifadeler ise rehberde "İSG Kurulu” başlı̆̆ı altında bulunup yasal boşluk içeren ifadeler kodu ile kodlanmıştır. İSG kurulları hakkında yönetmelikte yer alan hangi şartlarda ve kimlerden oluşan bir kurul kuracağına ilişkin maddeler rehberde geçen ifadeleri karşılamamaktadır.

“Ayrıca ihtiyaca göre kurulan kurullarda akademik birimler özelinde yapılanmaya gidilebilir”.

"Böyle bir yapılanmada tehlike sınıflarına göre gruplama yapılması da uygun olacaktır".

"Bir başka deyişle üniversite bünyesinde birden fazla sicil numarası olsa dahi yapılacak İSG profesyoneli görevlendirmelerinde de İSG kurulu oluşturulurken değerlendirmeye alınan yerleşke bazlı ya da faaliyet bazlı yaklaşım göz önünde bulundurulabilir”.

\section{Sonuç}

Rehberde üniversitelerin büyüklük, öğrenci sayısı, farklı yerleşkelere sahip olması gibi faktörleri gözeterek kurulacak yapının etkin ve verimli çalışmayı sağlayabilecek şekilde belirlenmesine vurgu yapılmıştır. Rehber üniversitede kurulacak İSG yapısını ağırlıklı olarak "yerleşke" kavramı üzerinden şekillendirmiştir. Tüm birimleri aynı yerleşke içerisinde bulunan üniversiteler birimlerini tehlike sınıfına göre olduğu gibi farklı birimleri farklı ilçelerde yer alan pek çok üniversite vardır.

Rehberde yer alan yerleşke tabanlı yapılanma üniversiteler için "işyeri” kavramını biraz daha açık hale getirmiştir. Ancak 6331 sayılı İSG Kanunu'nun yürürlüğe girmesi ile özellikle kamuda en fazla tartışma konusu işverenin kim olduğu sorusu olmuştur. Üniversitelerin İSG iç yönergelerine de bu durum yansımış; bazı üniversiteler işvereni devlet, bazıları rektör, bazıları ise birim yöneticileri olarak tanımlamıştır. 2547 sayılı Yükseköğretim Kanunu'nda "Rektör, üniversite veya yüksek teknoloji enstitüsü tüzel kişiliğini temsil eder." hükmü bulunmaktadır. Rehber de bu ifadeye vurgu yaparak "üniversitelerin sahip olduğu tüzel kişilik işveren, bu işverenin vekili ise rektördür" denilmektedir. Ayrıca rektör müteselsilen sorumluluğu saklı kalmak kaydı ile İSG konusunda üniversitelerde iş ve işlemleri düzenlemek ve 6331 sayılı Kanun'da belirtilen fiilleri yerine getirtmek üzere bir İSG işveren vekili belirleyebilir. Yapılan çalışmalar ve uygulama örneği değerlendirmeleri sonucunda üniversiteler özelinde; rektör veya rektör yardımcısı İSG işveren vekili olarak belirlenebilir. Birimin yönetiminde görev alan, yöneticiler; dekan, müdür, genel sekreter, daire başkanları, fakülte, enstitü, yüksekokul ve meslek yüksekokul sekreterleri, başhekim vb. işveren vekili olarak görev yapmaktadır. Bu durumun rehbere eklenmesi tarafları ve sorumluluklarını açıklayıcı olacaktır.

Rehberde işverenin hangi şartlarda ve kimlerden oluşan bir kurul kuracağına ilişkin maddeler 6331 sayılı İSG Kanunu ve "İSG Kurulları Hakkında Yönetmelik maddeleri esas alınarak sıralanmaktadır. Farklı yerleşkelerde faaliyet gösteren birimlerin tehlike sınıfları da gözetilerek yerleşke bazlı kurulların oluşturulabileceği örneklerle açıklanmıştır.

Kamu Üniversitelerinde İSG Uygulama Rehberinde; "Çalışmaların verimli ve etkin bir şekilde ilerlemesi gerektiği de göz önünde bulundurularak yerleşke bazlı ya da faaliyet bazlı olarak kurul yapılanmasına gidilebilmektedir" ifadesinden sonra yerleşke bazlı İSG kurulu oluşturmaya yönelik örnek verilmektedir. Kamu İSG rehberi ve mevzuat göz önüne alındığında İSG kurulları oluşturulurken, işyeri ve tehlike sınıfından bağımsız olarak yerleşke bazlı oluşturulması uygulamada yeni farklılıklar ortaya çıkaracaktır.

Ancak sistemde kayıtlı bulunan SGK sicil numaralarına göre aslında farklı farklı işyeri olarak tanımlanmış olan birimlerin 50 ve üzerinde çalışanı olması durumunda kendi içinde kurul oluşturması da gerekmektedir. İSG Kurulları Hakkında Yönetmeliğin 5. Maddesinde "İşverene bağl1, fabrika, müessese, işletme veya işletmeler grubu gibi birden çok işyeri bulunduğu hallerde elli ve daha fazla çalışanın bulunduğu her bir işyerinde ayrı ayrı kurul kurulur" hükmü yer almaktadır. Üniversite çatısı altında bulunan işyerlerinin iyi analiz edilmesi ve kurulların oluşturulması önemlidir. Birden fazla 
Kayabaşı, R., Özdemir, $\mathcal{H}$. \& Cündübeyoğlu, i., (2021). Kamu üniversitelerinde iş sağ l̆ğ $i$ ve güvenlĭğ uygulama rehberi içerik analizí.

kurulun ayrı ayrı toplanıyor olması kurullar arasında koordinasyon ve bilgi alışverişi ihtiyacını ortaya çıkarır ki çoğu üniversitede "üst kurul" olarak adlandırılan yapı rehberde İSG koordinasyon kurulu olarak karşımıza çıkmaktadır. İSG koordinasyon kurulunda ve İSG kurulunda mevzuat gereği bulunması gereken ve rehberdeki tavsiyelerden yola çıkılarak oluşturulan kurullar Tablo 6'da verilmiştir.

\title{
Tablo 6
}

Üniversitelerde ISG Koordinasyon Kurulu ve ISG Kurulu Üyeleri

\section{Üniversitelerde İSG Koordinasyon Kurulu Üyeleri \\ Yönetmeliğe Göre İSG Kurul Üyeleri}

\author{
Rektör, Rektör Yrd. \\ İş güvenliği uzmanı \\ İşyeri hekimi \\ İdari ve Mali İşler Daire Başkanı ve/veya \\ Personel Daire Başkanı \\ Bulunması halinde sivil savunma uzmanı \\ İSG Kurulu başkanları \\ Birim Temsilcileri (Kurulu olmayan fakülte, \\ MYO vb.) \\ Çalışan temsilcisi \\ Yapı İşleri ve Teknik Daire Başkanı
}

\author{
İşveren veya işveren vekili (Birim Yöneticisi) \\ İş güvenliği uzmanı \\ İşyeri hekimi \\ İnsan kaynakları, personel, sosyal işler veya idari \\ ve mali işleri yürütmekle görevli bir kişi \\ Bulunması halinde sivil savunma uzmanı \\ Çalışan temsilcisi
}

Bulunması halinde formen, ustabaşı veya usta

Her kampüsü ve her İSG kurulunu temsil edecek bir üyenin koordinasyon kurulunda bulunmas1 gerekmektedir. Bu durum tüm kampüs ve birimlerin üst kurulda temsil edilmesini sağlayarak düzeltici ve önleyici faaliyetlerin yürütümünü kolaylaştıracaktır. Üniversite İSG koordinasyon kurulunun rehbere göre işveren/işveren vekili başkanlığında yılda en az 2 kez toplanması tavsiye edilmiştir.

6331 sayılı İSG Kanunu'nun 38. Maddesi (a) bendinde kamu kurumları ile 50'den az çalışanı olan ve az tehlikeli sınıfta yer alan işyerleri için kanunun 6 . ve 7. Maddelerinin yürürlüğe gireceği tarihi 31/12/2023 olarak yer almaktadır. Bu tarihe kadar işverenin, bu işyerlerinde iş güvenliği hizmetleri sunumu için İSG profesyonelleri ile sözleşme yapması gerekmemekte ancak işveren, kanundaki bu maddeler dışında kalan tüm yükümlülüklerini de yerine getirmek zorundadır. Kamuda 4857 sayılı İş Kanunu'nun mülga 81 inci maddesi kapsamında çalışanlar hariç tutulmuştur (6331 İSG Kanunu, 2012).

Hazırlanmış olan rehberde de 696 sayılı Kanun Hükmünde Kararname'nin 113. Maddesi gereğince kamu kurum ve kuruluşlarında hizmet alımı yoluyla çalışan sürekli işçiler kadrolu işçi pozisyonlarına atandıklarını, aynı kararnamenin 83. Maddesinde ise kadro ya da sürekli işçi pozisyonuna geçirilen işçilerin kadroya geçmeden önceki işkolları korunarak yeni pozisyonlarına atanmaları gerektiği ifade edilmektedir. Bu işçiler için kamuda 50 ve üzeri çalışanı bulunan az tehlikeli sınıfta yer alan, 50'den az çalışanı bulunan tehlikeli ve çok tehlikeli işyerlerinde iş güvenliği uzmanı ve işyeri hekimi görevlendirme ile sözleşme yapma zorunluluğu vardır.

Rehberde verilen örnekte aynı kampüs içerisinde bulunan hizmet binaları çalışma alanları tanımlanmak şartıyla, ortak bir onaylı defter üzerinden faaliyetlerini sürdürebilecekleri yer almaktadır. Sürekli işçi pozisyonunda çalışanların yer aldığı SGK sicil numarasına sahip her işyeri için İSG-Kâtip üzerinden veya görevlendirme belgesi ile iş güvenliği uzmanı ve işyeri hekimi görevlendirilmelidir.

Sağlık gözetimi, risk değerlendirmesi gibi konularda Kamu İSG Rehberine atıfta bulunulmuştur. 6331 sayılı yasada "Bu Kanun kapsamında alınması gereken sağlık raporları işyeri hekiminden alınır. 50 'den az çalışanı bulunan ve az tehlikeli işyerleri için ise kamu hizmet sunucuları veya aile 
hekimlerinden de alınabilir." hükmü yer almaktadır. Kamu İSG Rehberinde çalışanların sağlık gözetiminin işyeri hekimi tarafından yapılması gerektiği vurgulanmış fakat kamu kurum ve kuruluşlarında işyeri hekimi çalıştırma zorunluluğu başlamamıştır. 50'den fazla çalışanı olan üniversiteler çalışanlarının işe giriş ve periyodik muayenelerinin yapılmasında sorunlarla karşılaşmaktadır. Kamu hizmet sunucularından alınan raporlarda İşyeri Hekimi ve Diğer Sağlık Personelinin Görev, Yetki, Sorumluluk ve Eğitimleri Hakkında Yönetmeliğinin EK-2'sinde yer alan işe giriş/periyodik muayene formu örneğine uygun olacak şekilde bir düzenleme bulunmamaktadır. 4857 sayılı İş Kanunu kapsamında çalışanlar için işyeri hekimi görevlendirilebilmektedir. İşyeri hekiminin çalışanların sağlık gözetimine ilişkin talep edeceği tetkiklerin kamu hizmet sunucularında yapılması için sistemli bir yapılanma bulunmamaktadır.

Rehberde risklerin etkin şekilde yönetilmesi adına tüm İSG tedbirlerinin hayata geçirilmesi, İSG kültürünün üniversitedeki tüm personel tarafından benimsenmesi için yönetimin İSG uygulamalarına verdiği desteği somut örneklerle uygulamalarının son derece önemli ve belirleyici olduğu belirtilmiştir. Yönetim tarafından bir İSG politikasının belirlenmesine vurgu yapılmakta ve belirlenen politikaların tüm çalışanlara duyurulması gerektiği ifade edilmektedir. İşyerinde benimsenen İSG politikaları ve bu politikalara bağlı görülen uygulamalar ve sonuçları, çalışanların işyeri örgütüne bağlılığını etkilemektedir (R. Kayabaşı, 2019, ss. 2-3). Üniversite yönetiminin İSG politikalarını yayınlaması ve güncellemesi İSG yönetim sisteminin oluşmasını sağlayacaktır. Planlamalardan uygulamalara her aşamada değerlendirmelerin yapılması ve yeni verilere göre düzeltici ve önleyici faaliyetlerin yürütülmesini sağlayacaktır.

İSG yönetim biriminin üniversite genelinde yapılacak tüm İSG çalışmalarına hem planlama hem de uygulama açısından doğrudan müdahil olması gerektiği, üniversitenin diğer birimlerini ilgilendiren çalışmalarda İSG işveren vekili eli ile gerekli talimatlandırmanın yapılması etkinliğini artıracağ ifade edilmektedir. İSG yönetim biriminin kimlerden oluşacağı rehberde ifade edilmemektedir. İSG yönetim biriminde yer alan kişilerin görev yetki ve sorumlulukları düzenleyen mevzuat alt yapısı bulunmamaktadır. İSG yönetim biriminin, işveren vekiline bildirimleri nasıl yapacağ ifade edilmemiştir. İSG'ne ilişkin yapılacak tespit ve öneriler onaylı defter suretiyle iş güvenliği uzmanı ve işyeri hekimi tarafından yapılmaktadır. Kamu kurumlarında iş güvenliği uzmanı ve işyeri hekimi görevlendirme zorunluluğunun henüz başlamamış olması defterin mühürlenmesi ve onaylanmasının önüne geçmektedir. Oysa onaylı deftere yazılan tespit ve öneriler işverene tebliğ edilmiş sayılmaktadır. İSG yönetim biriminde yer alan kişilerin, işverene veya vekiline tespit ve önerilerini tebliğ edebileceği bir mekanizma rehberde belirtilmemiştir.

\section{Tartışma ve öneriler}

Kamu Üniversitelerinde İSG Uygulama Rehberi kamu üniversitelerinde çalışanlar, işveren ve işveren vekillerine, mevzuat hükümlerini pratik olarak uygulamalarına yönelik çıkarılmıştır. Üniversitelerde görülen farklı teşkilat yapısı, kampüs ve yerleşkelerde görülen farklılıklar giderilmeye ve uygulama birliğine varılmak istenilmiştir. Bu kapsamda görülen farklı uygulamalar yanlış olmamakla birlikte mevcut şartlara bağlı geliştirilen çözümler olarak görülebilir. Uygulama birlikteliğinin olması denetleme açısından ve hukuki açıdan uygulamaların değerlendirilebilir olmasını sağlayacaktır.

Üniversite bünyesinde tek bir kurul kurulması durumunda rektörün ya da yetkili rektör yardımcısının işveren vekili olarak kurula başkanlık etmesinin uygun olacağı ifade edilmiş̧tir. Birden fazla kurul oluşturulması durumunda; bu kurulların kurul başkanı/işveren vekili ve üyelerinin kimlerden oluşacağ ifade edilmemiştir.

Sağlı gözetimine yönelik uygulama birliğini sağlayacak mevzuat düzenlemeleri yapılmalıdır.

İSG Profesyonellerinin kamu kurum ve kuruluşlarında memurlar için görevlendirilmesi henüz yürürlüğe girmemiştir. Bu görevleri yürütecek kişilerin belirlenmesi ve görevlendirilmesinde yasal boşluk içerdiği için zorluklar yaşanmaktadır. 
Kayabaşı, R., Özdemir, $\mathcal{H}$. \& Cündübeyoğlu, i., (2021). Kamu üniversitelerinde iş săglı̆g $\imath$ ve güvenlĭğ uygulama rehberi içerik analizi.

Çalışmanın sonuçları bağlamında araştırmacılar, rehberle üniversiteler içindeki İSG yapılanmalarını ve uygulamalarını ortaya koyan çalışmalar yapabilirler. Ayrıca üniversitelerin İSG sistemi kurabilmeleri için bir model önerisinde bulunabilirler.

\section{Araştırmanın etik yönü}

Yapılan bu çalı̧̧mada "Yükseköğretim Kurumları Bilimsel Araştırma ve Yayın Etiği Yönergesi" kapsamında uyulması belirtilen tüm kurallara uyulmuştur. Yönergenin ikinci bölümü olan "Bilimsel Araştırma ve Yayın Etiğine Aykırı Eylemler" başlığı altında belirtilen eylemlerden hiçbiri gerçekleştirilmemiştir.

$\mathrm{Bu}$ araştırmanın etik kurul izni gerektirmeyen araştırmalardan olduğunu beyan ederiz.

\section{8. Çıkar çatışması beyanı}

Çalışmanın yazar/tüm yazarları bu çalışmada, sonuçları veya yorumları etkileyebilecek herhangi bir maddi veya diğer asli çıkar çatışması olmadığını beyan ederiz.

\section{Katkı oranı}

Yazarlar makaleye eşit oranda katkı sağlamış olduklarını beyan ederiz.

\section{KAYNAKÇA}

Arastaman, G., Fidan, İ. Ö., \& Fidan, T. (2018). Nitel araştırmada geçerlik ve güvenirlik: Kuramsal bir inceleme. YYÜ Eğitim Fakültesi Dergisi, 15(1), 37-75.

Baytekin, O. F., \& Kaynar, E. (2021). Rehberlik araştırma merkezi denetim rehberinin incelenmesi. EUluslararası Eğitim Araştırmaları Dergisi, 12(1), 89-103.

Berk M., Önal B., \& Güven R. (2011). Meslek hastalıkları rehberi. Çalışma ve Sosyal Güvenlik Bakanlığg1, 7-27.

Bilir, N. (2016). İş sağllğg ve güvenliği profili: Türkiye. Çalışma ve Sosyal Güvenlik Bakanlığı. https://www.csgb.gov.tr/medias/4578/kitap09.pdf

Cumhur, A., \& Ahıskalı, H. (2018). İş sağlığı ve güvenliği uygulamaları: Hitit Üniversitesi örneği. Mesleki Bilimler Dergisi (MBD), 7(2), 310-319.

Çal1k, M., \& Sözbilir, M. (2014). Parameters of content analysis. Education and Science, 33-38.

Çivi, G. (08-11 Mayıs, 2016). Üniversitelerde iş sağlığ1 ve güvenliği yönetiminin yapılandırılması ve sürdürülebilirliği. 8. Uluslararası İş Săgllğg ve Güvenliği Bildiri Tam Metin Kitabı içinde (ss. 512-519), Türkiye: İstanbul.

Gül, A., Akman, Ü., \& Özay, M. E. (2018). Hastanelerde hizmet veren taşeron yemek şirketlerinde iş sağlığ1 ve güvenliği. OHS Academy, 1(2), 83-97.

Güngör, A. A. (2020). Özel öğrenci etüt eğitim merkezi rehberlik ve denetim rehberinin yasal belgeler ve alanyazın temelinde incelenmesi. E-Uluslararası Eğitim Araştırmaları Dergisi, 11(3), 90109.

Hepkul, A. (2002). Bir sosyal bilim araştırma yöntemi olarak içerik analizi. Anadolu Üniversitesi Iktisadi ve İdari Bilimler Fakültesi Dergisi, 18(1), 1-12. 
Kayseri Üniversitesi Sosyal Bilimler Dergisí. Ciltt 3, Sayi: 2, Aralik 2021, 29-45

Kayseri University Journal of Social Sciences. Vol 3, NNo: 2, December 2021, 29-45

İş Sağlığı ve Güvenliği Kanunu. (20 Haziran 2012). Resmî Gazete (Sayı: 28339). https://www.mevzuat.gov.tr/MevzuatMetin/1.5.6331.pdf

İş Sağlığı ve Güvenliğine İlişkin Tehlike Sınıfları Tebliğ. (26 Aralık 2012). Resmî Gazete. (Sayı: 28509).

https://www.mevzuat.gov.tr/mevzuat?MevzuatNo=16909\&MevzuatTur=9\&MevzuatTertip=5

Kamu Üniversitelerinde İş Sağlığı ve Güvenliği Uygulama Rehberi (2021). https://www.csgb.gov.tr/media/75778/kamu-uni-isg_19-04-21.pdf

Karataş, Z. (2015). Sosyal bilimlerde nitel araştırma yöntemleri. Manevi Temelli Sosyal Hizmet Araştırmaları Dergisi, 1(1), 62-80.

Kayabaşı, R. (2019). İşyeri iş sağlığı ve güvenliği politikalarının çalışanların örgütsel bağlılığına etkisi. Mesleki Bilimler Dergisi (MBD), 8 (2), 133-143.

Keçeci, Ş. (2021). Ulusal tez merkezinde yer alan iş sağlığı güvenliği alanında yazılmış tezlerin bibliyometrik analizi. Uluslararası Sosyal Bilimler ve Eğitim Dergisi, 3(4), 51-68.

Krippendorff, K. (2018). Content analysis: An introduction to its methodology. Los Angeles, SAGE, 35.

Mutlu, N. G., \& Altuntaş, S. (2016). Türkiye'de 1974-2016 yıllarında iş sağlığ1 ve güvenliği alanında yapılan lisansüstü tezlerin profili. Karaelmas Fen ve Mühendislik Dergisi, 7(2), 509-535.

Özdemir, H., \& Gündüz, E. (06-09 Mayıs, 2018). Türkiye'de iş sağlığ1 ve güvenliği alanında yapılan lisansüstü tez çalışmalarına yönelik bir içerik analizi. 9.Uluslararası İş Sağlı ̆̆g ve Güvenliği Kongresi Bildiri Tam Metin Kitabı içinde (ss. 454-470), Türkiye: İstanbul.

SGK (2021). İş kazası, meslek hastalığı ve iş göremezlik istatistikleri. http://www.sgk.gov.tr

Şahin, R., Özkan, S., \& İlhan, M. N. (2019). Akademisyenlerde iş sağlığı ve iş sağlığını etkileyen faktörler. Gazi Sağllk Bilimleri Dergisi, 4(1), 11-18.

Şensöğüt, C. (2018). İş güvenliği kültürü ve üniversiteler. Soma Meslek Yüksekokulu Teknik Bilimler Dergisi, 1(25), 9-15.

Tonbul, Y., \& Çiğdem, G. A. (2020). Bilsem denetim rehberinin yasal belgeler ve alan yazın temelinde. E-International Journal of Educational Research, 11(3), 36-62.

Toprakç1, E., \& Bulut, A. (2021). Ortaokul denetim rehberinin alan yazın ve yasal belgeler temelinde incelenmesi. Uluslararası Eğitim Araştırmaları Dergisi, 12(1), 16-35.

Ulutaşdemir, N., Tuna, H., \& Ertürk, İ. (2019). İş sağlığı ve güvenliği alanında Türkiye'de yapılan lisansüstü tez çalışmalarının incelenmesi. Gümüşhane Üniversitesi Sosyal Bilimler Enstitüsü Elektronik Dergisi, 10(1), 32-41.

Yüksel, Y., (2015). İçerik çözümlemesi. https://www.academia.edu/24209083/\% C4\% B0\% C3\% 87ER\% C4\% B0K_\% C, 3(87), C3. 